\title{
Acanthosis nigricans in obese Chinese children
}

\author{
HY Ng *, Jack HM Young, KF Huen, Louis TW Chan
}

\section{A B S T R A C T}

Objectives: To investigate the demographic characteristics and insulin resistance in local overweight/obese Chinese children with and without acanthosis nigricans, and the associations of acanthosis nigricans with insulin resistance and other cardiometabolic co-morbidities.

Design: Case series with cross-sectional analyses.

Setting: A regional hospital in Hong Kong.

Patients: Chinese children assessed between January 2006 and December 2010 at Tseung Kwan O Hospital for being overweight or obese.

Main outcome measures: The demographics, anthropometric data, acanthosis nigricans status, and biochemical results were analysed.

Results: A total of 543 overweight/obese children were studied with $64 \%$ being boys and $29 \%$ had insulin resistance. Adolescents aged 12 to 18 years, compared with children aged 5 to 11 years, were more likely to have acanthosis nigricans $(63 \%$ vs $47 \%$; $\mathrm{P}<0.001)$ and insulin resistance $(37 \%$ vs $25 \%$; $\mathrm{P}=0.005)$. Compared with overweight children, those who were obese were more likely to have the two conditions: acanthosis nigricans (59\% vs $44 \% ; \mathrm{P}=0.005)$ and insulin resistance (35\% vs $19 \%$; $\mathrm{P}=0.001)$. Compared with those without acanthosis

This article was published on $25 \mathrm{Apr}$ 2014 at www.hkmj.org. nigricans, those with the condition had significantly

higher mean values for systolic blood pressures *Corresponding author: nghypatrick@gmail.com

$(\mathrm{P}<0.001)$, 2-hour post-oral glucose tolerance test glucose level $(\mathrm{P}=0.021)$, fasting insulin level $(\mathrm{P}<0.001)$, homeostasis model of assessmentinsulin resistance $(\mathrm{P}<0.001)$, fasting triglyceride level $(P<0.001)$, and alanine aminotransferase level $(\mathrm{P}=0.002)$, but a lower high-density lipoprotein cholesterol level $(\mathrm{P}<0.001)$. Those with acanthosis nigricans were also more likely to have insulin resistance $(\mathrm{P}<0.001)$, hypertension $(\mathrm{P}=0.021)$, fatty liver $(\mathrm{P}=0.001)$, and abnormal glucose homeostasis $(\mathrm{P}=0.003)$.

Conclusion: Obese Chinese children and adolescents with acanthosis nigricans had a higher chance of having insulin resistance and cardiometabolic comorbidities. Acanthosis nigricans is an important clinical feature warranting early attention and evaluation to facilitate timely interventions and monitoring.

\section{Hong Kong Med J 2014;20:290-6 DOI: $10.12809 / \mathrm{hkmj} 134071$}

$\mathrm{HY} \mathrm{Ng}{ }^{*}, \mathrm{MB}, \mathrm{ChB}, \mathrm{MRCPCH}$

JHM Young, MB, ChB, MRCPCH

KF Huen, FHKCPaed, FHKAM (Paediatrics)

LTW Chan, FHKCPaed, FHKAM (Paediatrics)

Department of Paediatrics and Adolescent Medicine, Tseung Kwan O Hospital, Tseung Kwan O, Hong Kong

New knowledge added by this study

- Hong Kong Chinese children with acanthosis nigricans were more likely to have insulin resistance, hypertension, fatty livers, and abnormal glucose homeostasis.

Implications for clinical practice or policy

- In children, acanthosis nigricans is an important clinical sign warranting early attention and evaluation.

\section{Introduction}

Obesity was formally recognised as a global epidemic by the World Health Organization (WHO) in $1997 .{ }^{1}$ During the past decades, the prevalence of being overweight and obese has increased substantially. In Hong Kong, 17\% of children were overweight/obese in $2005 / 6$, which was a $5 \%$ increase since 1993 , based on International Obesity Task Force cut-offs. ${ }^{2}$

Overweight/obese children and adolescents are more likely to have hyperinsulinaemia, hypertension, and dyslipidaemia. ${ }^{3}$ The clustering of cardiometabolic risk factors in these patients tends to track into adult life. ${ }^{3}$ However, the Diabetes
Prevention Program demonstrated that lifestyle interventions could prevent or postpone the onset of type 2 diabetes mellitus (DM) by $58 \%$ in adults. ${ }^{4}$ Thus, identifying at-risk groups may allow early interventions and prevention of potential cardiometabolic complications.

Acanthosis nigricans (AN)-a hyperpigmented, thickened, and velvety dermatosis at the nape of the neck or axilla-is an easily identifiable physical sign. ${ }^{5}$ The American Diabetes Association includes it as an indicator of DM risk in overweight youths entering puberty. ${ }^{6}$ Yet, some authors have argued that it is not an independent predictor of insulin resistance (IR) if body mass index (BMI) is controlled for. ${ }^{7}$ 
Ethnic differences occur in obesity indices and their associated risk factors include IR ${ }^{8}$ Local studies focusing on associations between AN with IR and other cardiometabolic co-morbidities in Chinese paediatric age-groups are sparse. In this regional centre study, we describe the demographic characteristics and IR in obese Chinese children with and without AN, with a focus on exploring the associations of AN with IR and other cardiometabolic co-morbidities.

\section{Methods}

A retrospective study was conducted by recruiting overweight/obese children and adolescents between 5 and 18 years of age who underwent obesity assessment between January 2006 and December 2010 in a regional hospital in Hong Kong. Patients were excluded if they had underlying metabolic diseases, chronic diseases, or other medical conditions resulting in obesity. Patients taking on medications that would alter metabolic profiles were also excluded.

Anthropometric data and AN status were recorded. Blood samples were collected. Ultrasound liver scans were performed on patients with elevated alanine aminotransferase (ALT) levels. Height was measured to the nearest $0.1 \mathrm{~cm}$ using the Harpenden stadiometer (Holtain; Crymych, UK) and body weight to the nearest $0.1 \mathrm{~kg}$ with light clothing using an electronic column scale (SECA780; Seca Ltd, Hamburg, Germany). The BMI $\left(\mathrm{kg} / \mathrm{m}^{2}\right)$ percentiles of 90th and $97 \mathrm{th}$ centiles were used to define overweight and obesity, respectively. ${ }^{9,10}$ Local percentile standards were based on a local population survey conducted in 1993. ${ }^{11}$ The BMI z-score was calculated using this local age- and gender-specific reference. Blood pressure (BP) was measured using the standard oscillometric method (BP-8800C; Colin Electronics, Komaki, Japan) in the daytime with the children seated and rested. Average BP was obtained from two measurements. The BP z-score was calculated using the local BP reference. ${ }^{12}$ Participants were considered hypertensive if the mean systolic BP z-score and/or diastolic BP (DBP) $\mathrm{z}$-score was/were greater than or equal to the 95 th centiles for age and gender.

The diagnosis of AN was made by paediatricians; additional scoring for this entity was not undertaken as not all authors agreed that specific quantitative scales could improve the accuracy of IR prediction. $^{13}$

Blood samples for plasma glucose, insulin, lipid profile, and liver enzymes following an overnight fasting were obtained and a standard oral glucose tolerance test (OGTT) was performed. The homeostasis model of assessment (HOMA)IR value was used to assess IR using the following equation: fasting glucose $(\mathrm{mmol} / \mathrm{L}) \mathrm{x}$ fasting insulin

\section{華籍肥胖兒童中的黑棘皮病}

\section{吳克勇、楊康明、禤桂芬、陳子宏}

目的：探討本地超重或肥胖兒童的人口特徵和胰島素抗性，以及黑棘 皮病與胰島素抗性和其他心血管代謝共病的關係。

設計：病例系列與橫斷面分析。

安排：香港一所分區醫院。

患者：2006年1月至2010年12月期間因超重或肥胖於將軍澳醫院接受 評估的華籍兒童。

主要結果測量：人口學及人體測量數據、黑束皮病的情況和生化結果 分析。

結果：共分析了543名超重或肥胖的兒童，其中64\%為男孩，29\% 有胰島素抗性。與5至 11 歲的兒童相比, 12 至 18 歲的青少年有較 高機會患有黑棘皮病（63\%比47\%； P<0.001）和出現胰島素抗性 （37\%比 $25 \% ； \mathrm{P}=0.005$ ）。相比超重兒童, 肥胖兒童有較高機會患 有黑棘皮病（ $59 \%$ 比 $44 \% ; \mathrm{P}=0.005)$ 和胰島素抗性（35\%比19\%; $\mathrm{P}=0.001)$ 。相對於那些沒有黑棘皮病的兒童, 患有此症的兒童在 以下幾方面有明顯較高的平均值水平：收縮壓 $(\mathrm{P}<0.001)$ 、口 服葡萄糖溶液後兩小時血糖水平 $(\mathrm{P}=0.021)$ 、空腹胰島素水平 $(\mathrm{P}<0.001)$ 、胰島素抵抗指數 $(\mathrm{P}<0.001)$ 、空腹甘油三酯水平 $(\mathrm{P}<0.001)$ 和丙氨酸氨基轉移酶水平（ $\mathrm{P}=0.002 ）$ ，但卻有較低的 高密度脂蛋白膽固醇水平 $(\mathrm{P}<0.001)$ 。那些患有黑棘皮症的兒童也 有較高機會出現胰島素抗性 $(\mathrm{P}<0.001)$ 、高血壓 $(\mathrm{P}=0.021)$ 、脂 肪肝 $(\mathrm{P}=0.001)$ 和異常的葡萄糖穩態 $(\mathrm{P}=0.003)$

結論：患有黑棘皮病的肥胖兒童和青少年出現胰島素抗性和患有心血 管代謝共病的機會較高。黑棘皮病是一種重要的臨床症狀, 須及早診 治, 以便及時的干預和監控。

$(\mu \mathrm{U} / \mathrm{mL}) / 22.5 .^{14}$ Any HOMA value of $\geq 4$ was considered to indicate IR. Glucose abnormalities were defined according to criteria from the WHO. ${ }^{15}$ Abnormal glucose homeostasis was referred to any combination of impaired fasting glucose, impaired glucose tolerance, or DM on the basis of fasting or 2-hour plasma glucose levels in the OGTT. ${ }^{16,17}$ Fatty liver was diagnosed by ultrasound scan affirmed by the operational definition of non-alcoholic fatty liver disease in the Asia-Pacific region. ${ }^{18}$

\section{Statistical analyses}

The statistical analyses were conducted using the Statistical Product and Service Solutions (version 17.0 for Windows 7 ). Taking $\mathrm{P}<0.05$ as statistically significant, Student's $t$ test and Wilcoxon rank-sum test were used to compare results with a normal and skewed distribution, respectively. The Chi squared test or Fisher's exact test as appropriate were used to analyse categorical variables. Multiple logistic regression analysis was then performed to identify independent factors associated with IR. To avoid multicollinearity, body weight and height were not 
used in the model, since both variables correlated highly with BMI. For the same reason, fasting insulin and glucose levels were not selected for the model as the HOMA-IR was derived from them. The model was simplified in a backward stepwise fashion by removing variables with $P$ values of $>0.1$. Goodnessof-fit of the regression model was tested with the Hosmer-Lemeshow test.

\section{Results}

A total of 543 overweight/obese Chinese patients were included in this study. They had a mean \pm standard deviation age of $12 \pm 3$ years and $64 \%$

TABLE I. Basic characteristics of 543 children

\begin{tabular}{|c|c|}
\hline Characteristics & $\begin{array}{l}\text { No. }(\%) \text { of patients } \\
{[\text { [mean } \pm \text { SD] }}\end{array}$ \\
\hline \multicolumn{2}{|l|}{ Age (years) } \\
\hline All & $543[12 \pm 3]$ \\
\hline $5-11$ & $251(46)[10 \pm 2]$ \\
\hline $12-18$ & $292(54)[14 \pm 2]$ \\
\hline \multicolumn{2}{|l|}{ Sex } \\
\hline Male & $346(64)$ \\
\hline Female & $197(36)$ \\
\hline \multicolumn{2}{|l|}{$\mathrm{BMI}$} \\
\hline Overweight: 90-97\% & $124(23)$ \\
\hline Obese: $>97 \%$ & $419(77)$ \\
\hline \multicolumn{2}{|l|}{ Acanthosis nigricans ${ }^{*}$} \\
\hline Present & $295(54)$ \\
\hline Absent & $237(44)$ \\
\hline \multicolumn{2}{|l|}{ Insulin resistance $†$} \\
\hline HOMA-IR $<4$ & $341(63)$ \\
\hline HOMA-IR $\geq 4$ & $156(29)$ \\
\hline
\end{tabular}

TABLE 2. Comparison of acanthosis nigricans and insulin resistance in subgroups

\begin{tabular}{lrlrl}
\hline Subgroup & AN present* & P value & $\begin{array}{c}\text { Insulin } \\
\text { resistance } \\
\text { (HOMA-IR } \geq 4) \dagger\end{array}$ & P value \\
\hline Age (years) & & & & \\
\hline $5-11$ & $115 / 247(47 \%)$ & $<0.001 \ddagger$ & $59 / 234(25 \%)$ & $0.005 \ddagger$ \\
$12-18$ & $180 / 285(63 \%)$ & & $97 / 263(37 \%)$ & \\
BMI & & & & \\
Overweight: $90-97 \%$ & $53 / 120(44 \%)$ & $0.005 \ddagger$ & $21 / 111(19 \%)$ & $0.001 \ddagger$ \\
\hline Obese: $>97 \%$ & $242 / 412(59 \%)$ & & $135 / 386(35 \%)$ & \\
\hline
\end{tabular}

Abbreviations: $\mathrm{AN}=$ acanthosis nigricans; $\mathrm{BMI}=$ body mass index; $\mathrm{HOMA-IR}=$

homeostasis model of assessment-insulin resistance

* Data of II children are missing

† Only 497 insulin resistance results are available

$\neq$ Chi squared tests $(n=346)$ of them were boys. The majority $(77 \%$, $n=419)$ were obese with a BMI of $>97 \%$. In all, AN was present in $54 \%(n=295)$ of the subjects and $29 \%(n=156)$ of them had IR. Relevant data are summarised in Table 1.

Table 2 illustrates that adolescents (aged 12-18 years), compared with younger children (aged 5-11 years), were more likely to have AN (63\% vs $47 \%$; $\mathrm{P}<0.001)$ and IR (37\% vs 25\%; $\mathrm{P}=0.005)$. Obese children, compared with overweight children, were also more likely to have $\mathrm{AN}$ ( $59 \%$ vs $44 \%$; $\mathrm{P}=0.005$ ) and IR (35\% vs $19 \%$; $=0.001$ ).

Table 3 shows baseline characteristics and biochemical parameters in children with and without AN. Apart from being older, the group with AN had higher mean 2-hour post-OGTT glucose $(\mathrm{P}=0.021)$, fasting insulin $(\mathrm{P}<0.001)$, triglyceride $(\mathrm{P}<0.001)$, and ALT $(\mathrm{P}=0.002)$ levels, but lower mean levels of highdensity lipoprotein (HDL) cholesterol $(\mathrm{P}<0.001)$. Their BMI $(\mathrm{P}<0.001)$, BMI $z$-score $(\mathrm{P}<0.001)$, systolic blood pressure (SBP) $[\mathrm{P}<0.001]$, and HOMA-IR values $(\mathrm{P}<0.001)$ were also higher. Notably, the higher SBP, when converted to SBP z-score (taking into account age and gender), was no longer significant. Both DBP and DBP z-scores showed no differences between the two groups. The presence of IR and other cardiometabolic co-morbidities in subjects with and without AN are also shown in Table 3. The frequencies of IR, hypertension, fatty liver, and abnormal glucose homeostasis were all significantly higher in subjects with AN.

Further analysis of risk factors for IR using the multiple logistic regression model showed that the presence of $\mathrm{AN}$ (odds ratio $[\mathrm{OR}]=2.36 ; 95 \%$ confidence interval $[\mathrm{CI}], 1.46-3.80 ; \mathrm{P}<0.001)$, older age $(1.17 ; 1.07-1.28 ; \mathrm{P}=0.001)$, higher triglyceride level $(1.91 ; 1.33-2.74 ; \mathrm{P}<0.001)$, and higher $\mathrm{BMI}$ z-score $(6.95 ; 3.40-14.16 ; \mathrm{P}<0.001)$ were significant independent variables predicting IR (Table 4). However, though HDL and 2-hour post-OGTT glucose level were borderline significant predictors for IR, their effect sizes were small. The HosmerLemeshow test of goodness-of-fit was 0.315, indicating a good logistic regression model fit.

\section{Discussion}

Obesity is a public health problem that has become epidemic worldwide. In the primary care setting, identifying children with AN may allow early implementation of interventions to prevent the development of DM and other cardiometabolic co-morbidities in overweight/obese children. ${ }^{16}$ Searching for AN over the neck is easy, non-intrusive. and acceptable to the children. ${ }^{19}$ Presence of AN can also be used as a grounds to initiate and reinforce discussions about lifestyle modification. ${ }^{5,19,20}$

An observed AN frequency of $54 \%$ in our subjects was consistent with data reported in the 
TABLE 3. Comparisons between the groups with and without acanthosis nigricans

\begin{tabular}{|c|c|c|c|}
\hline & \multicolumn{2}{|c|}{ No. (\%), mean \pm SD, or median (IQR) } & \multirow[t]{2}{*}{$P$ value } \\
\hline & With AN (n=295) & Without AN (n=237) & \\
\hline Age (years) & $12.4 \pm 2.5$ & $11.5 \pm 3.0$ & $0.001 \dagger$ \\
\hline $\operatorname{Sex}(M / F)$ & $183 / 112$ & $159 / 78$ & $0.227 \ddagger$ \\
\hline Body weight (kg) & $70.8(57.9-83.7)$ & $59.0(46.1-71.9)$ & $<0.001 \S$ \\
\hline Height (cm) & $156.4(146.9-164.0)$ & $149.8(137.5-161.0)$ & $<0.001 \S$ \\
\hline BMI $\left(\mathrm{kg} / \mathrm{m}^{2}\right)$ & $28.8(26.1-31.7)$ & $26.0(24.1-28.5)$ & $<0.001 \S$ \\
\hline z-Score & $2.3 \pm 0.4$ & $2.2 \pm 0.4$ & $<0.001 \dagger$ \\
\hline Systolic BP (mm Hg) & $119.5 \pm 9.3$ & $116.2 \pm 9.8$ & $<0.001 \dagger$ \\
\hline z-Score & $1.1 \pm 0.9$ & $1.0 \pm 0.9$ & $0.175 \dagger$ \\
\hline Diastolic BP (mm Hg) & $61.6 \pm 7.1$ & $60.7 \pm 7.4$ & $0.174 \dagger$ \\
\hline z-Score & $-0.3 \pm 0.9$ & $-0.3 \pm 0.8$ & $0.774 \dagger$ \\
\hline Fasting glucose (mmol/L) & $4.9 \pm 0.5$ & $4.9 \pm 0.4$ & $0.598 \dagger$ \\
\hline 2-Hour post-OGTT glucose (mmol/L) & $6.4 \pm 1.6$ & $6.1 \pm 1.1$ & $0.021 \dagger$ \\
\hline Fasting insulin $(\mu \mathrm{U} / \mathrm{mL})$ & $16.8(11.2-25.3)$ & $11.8(8.4-16.2)$ & $<0.001 \S$ \\
\hline HOMA-IR & $3.6(2.5-5.3)$ & $2.6(1.8-3.6)$ & $<0.001 \S$ \\
\hline Total cholesterol (mmol/L) & $4.4(4.0-5.1)$ & $4.5(4.0-5.0)$ & $0.913 \S$ \\
\hline LDL (mmol/L) & $2.6(2.1-3.1)$ & $2.5(2.1-3.0)$ & $0.535 \S$ \\
\hline $\mathrm{HDL}(\mathrm{mmol} / \mathrm{L})$ & $1.2(1.1-1.4)$ & $1.4(1.2-1.6)$ & $<0.001 \S$ \\
\hline Triglyceride (mmol/L) & $1.3(1.0-1.8)$ & $1.1(0.9-1.6)$ & $<0.001 \S$ \\
\hline ALT (units/L) & $24.0(17.0-41.0)$ & $20.0(15.0-32.0)$ & $0.002 \S$ \\
\hline Insulin resistance* & $118 / 275(43)$ & $36 / 215(17)$ & $<0.001 \ddagger$ \\
\hline Hypertension & $58(20)$ & $29(12)$ & $0.021 \ddagger$ \\
\hline Fatty liver & $44(15)$ & $14(6)$ & $0.001 \ddagger$ \\
\hline Abnormal glucose homeostasis & $39(13)$ & $13(5)$ & $0.003 \ddagger$ \\
\hline
\end{tabular}

Abbreviations: $\mathrm{ALT}=$ alanine aminotransferase; $\mathrm{AN}=$ acanthosis nigricans; $\mathrm{BMI}=$ body mass index; $\mathrm{BP}=$ blood pressure;

$\mathrm{HDL}=$ high-density lipoprotein; $\mathrm{HOMA}-\mathrm{IR}=$ homeostasis model of assessment-insulin resistance; $\mathrm{IQR}$ = interquartile range;

$\mathrm{LDL}=$ low-density lipoprotein; OGTT = oral glucose tolerance test; SD = standard deviation

* Insulin resistance (HOMA-IR) status and acanthosis nigricans status were available for analysis in 490 children

+ Student's $t$ test

$\ddagger$ Chi squared test

$\S$ Mann-Whitney U test

TABLE 4. Associations between clinical and laboratory parameters and insulin resistance according to the multivariate analysis

\begin{tabular}{|c|c|c|c|c|}
\hline \multirow[t]{2}{*}{ Item } & \multicolumn{2}{|c|}{ Insulin resistance ${ }^{*}$} & \multirow[t]{2}{*}{$P$ value } & \multirow[t]{2}{*}{ OR $(95 \% \mathrm{Cl})$} \\
\hline & Present & Absent & & \\
\hline Age (years) & $12.6 \pm 2.3$ & $11.7 \pm 2.9$ & 0.001 & $1.17(1.07-1.28)$ \\
\hline BMI z-score & $2.4 \pm 0.4$ & $2.2 \pm 0.3$ & $<0.001$ & $6.95(3.40-14.16)$ \\
\hline Acanthosis nigricans (+/-)† & $118 / 36$ & $157 / 179$ & $<0.001$ & $2.36(1.46-3.80)$ \\
\hline Triglyceride (mmol/L) & $1.5(1.1-2.0)$ & $1.1(0.9-1.5)$ & $<0.001$ & $1.91(1.33-2.74)$ \\
\hline $\mathrm{HDL}(\mathrm{mmol} / \mathrm{L})$ & $1.2(1.1-1.3)$ & $1.4(1.1-1.5)$ & 0.047 & $0.40(0.16-0.99)$ \\
\hline 2-Hour post-OGTT glucose ( $\mathrm{mmol} / \mathrm{L})$ & $6.6 \pm 1.7$ & $6.1 \pm 1.3$ & 0.053 & $1.16(1.00-1.36)$ \\
\hline
\end{tabular}

Abbreviations: $\mathrm{BMI}=$ body mass index; $\mathrm{Cl}=$ confidence interval; $\mathrm{HDL}=$ high-density lipoprotein; $\mathrm{HOMA}-\mathrm{IR}=$ homeostasis model of assessment-insulin resistance; OGTT = oral glucose tolerance test; $\mathrm{OR}=$ odds ratio

* Data are shown as mean \pm standard deviation, No., or median (interquartile range)

† Insulin resistance (HOMA-IR) status and acanthosis nigricans status were available for analysis in 490 children 
literature. ${ }^{21,22}$ Our adolescents were more likely to have AN than younger children, in line with hyperinsulinaemia being more severe among older individuals. ${ }^{22}$ In our study, development of AN showed no gender preference, as in a study of 1412 unselected children by Stuart et al. ${ }^{23}$ In our cohort and that in Nsiah-Kumi et al's study, ${ }^{13}$ obese children were more likely to have AN than overweight ones.

Whilst IR is a hallmark of obesity, it is also associated with other metabolic derangements and clinical or subclinical cardiovascular diseases. ${ }^{24} \mathrm{We}$ used the HOMA-IR value-a simple, validated, and practical marker of IR in the paediatric populationto give a more physiological estimate of glucose homeostasis, ${ }^{25}$ that was also shown to correlate well with the hyperinsulinaemic-euglycaemic glucose clamp technique, a gold standard for quantifying insulin sensitivity. ${ }^{24}$ In a local community-based cross-sectional study, it was shown that the mean HOMA-IR value was lower among Hong Kong Chinese adolescents than subjects in the United States. ${ }^{8}$ Currently, there is no worldwide consensus on defining IR among children. Some studies have chosen an HOMA-IR value as low as 2.7 while others have shown that a value of 4 can be present in pubertal children (because of the transient physiological IR during puberty). ${ }^{13}$ Although we do not have data about pubertal stage in our study subjects, an HOMA-IR of $\geq 4$ would be a conservative but reasonable definition of IR, in parallel with the threshold used in a multicentre trial in the United States (Studies to Treat or Prevent Pediatric Type 2 Diabetes-STOPP-T2DM). ${ }^{26}$

In our study, $29 \%$ of our cohort had IR using the cut-off HOMA-IR of $\geq 4$, and the mean value was higher among those with AN present (3.6 vs $2.6 ; \mathrm{P}<0.001)$. Notably, IR was more common among adolescents than young children (37\% vs $25 \% ; \mathrm{P}=0.005)$ as well as among obese than overweight subjects ( $35 \%$ vs $19 \%$; $\mathrm{P}=0.001)$. Goran et $\mathrm{al}^{27}$ suggested that long-standing obesity and the physiological IR during puberty accounted for adolescents having more AN and IR. They found that pubertal transition from Tanner I to Tanner III was associated with a $32 \%$ reduction in insulin sensitivity across different genders and ethnicities, and proved that body fat was the predominant factor influencing IR whereas total and visceral fat both contributed independently to lower insulin sensitivity. ${ }^{27}$ Notably, $25 \%$ of our young (5-11 years old) overweight/obese subjects already had IR, suggesting that the onset of metabolic derangement might have started long before adolescence and indicates that screening should begin early during childhood.

In our cohort, IR and other cardiometabolic co-morbidities were more prevalent among those with AN. The relationship of AN with hypertension may not be as strong as that with fatty liver and abnormal glucose homeostasis. This might be consistent with hypertension being more closely related to obesity than to $\mathrm{AN} .^{28}$ Nevertheless, studies assessing the relationship of $\mathrm{BP}$ and insulin levels are conflicting. ${ }^{29}$ Some authors postulate that the underlying pathophysiology is a common genetic predisposition to both IR and hypertension, whilst also involving other mechanisms. ${ }^{30}$

Dyslipidaemia is believed to play a central role in the development of heart diseases. High level of triglyceride and low level of HDL cholesterol are commonly used criteria to define metabolic syndrome both in children and adults. ${ }^{31}$ High triglyceride levels and the IR index (HOMA-IR) were strong, independent predictors of increased carotid intima-media thickness, which was a non-invasive measure of subclinical atherosclerosis in paediatric research. $^{32}$ Nevertheless, low HDL cholesterol level carried an even greater relative risk than high triglyceride levels. ${ }^{33}$ Compared with those without AN, subjects with the condition had a higher mean triglyceride level $(\mathrm{P}<0.001)$ but lower HDL level $(\mathrm{P}<0.001)$, and hence their future cardiovascular health seems to be of great concern.

Fatty liver, or non-alcoholic fatty liver disease (NAFLD), can be classified into isolated fatty liver in which there is only accumulation of fat, and nonalcoholic steatohepatitis (NASH) in which there is fat accumulation and damage to liver cells. Presence of the latter is associated with raised liver enzymes and more abnormal ultrasound scans. Our subjects with AN had higher levels of ALT $(\mathrm{P}=0.002)$ and a higher proportion with fatty livers. In contrast, Uwaifo et $\mathrm{al}^{34}$ reported that AN was not common among a small cohort of 28 subjects with biopsyproven $\mathrm{NASH}$, despite their high prevalence of IR. These authors therefore questioned the use of AN as an index of IR in patients with NASH. However, in our study liver ultrasounds were only performed in children with raised ALT levels. According to Sartorio et al, ${ }^{35}$ the ALT level alone was insufficient as a marker of NAFLD and the sensitivity of using its level to predict NAFLD was as low as $41 \%$ (depending on the cut-off used). Several prediction scores have been developed for non-invasive liver steatosis screening, but they have insufficient diagnostic accuracy among obese children. ${ }^{36}$

For DM, incidence, prevalence, and disease progression are believed to vary in different ethnic groups. The overall frequency of abnormal glucose homeostasis of $10 \%$ ( $8 \%$ impaired glucose tolerance and $2 \%$ with DM; data not shown) was lower than in a recent study by Brickman et a ${ }^{16}$ who reported a $29 \%$ frequency of abnormal glucose homeostasis among a group of 8-to-14 years old, mainly of Hispanic and African American children with AN. Another study from the United Kingdom found a higher frequency of type 2 DM among African-Caribbean 
and South Asian groups, while the Chinese and white Caucasians had the lowest frequencies. ${ }^{37}$ The reasons for such inter-ethnic differences are still unclear but do not seem to be solely genetic, as inter-generational social factors may also modify the evolution and biology of the disease. ${ }^{37}$ Our results, together with the recently reported sharp rise in the incidence of type 2 DM in Hong Kong children aged under 19 years after 2004,,38 should alert our health care professionals as to the importance of early detection of potential predictors of abnormal glucose metabolism such as AN.

Recently, the role of IR in cardiometabolic derangements has attracted more attention. Nevertheless, there is no prediction model for IR in our local children and adolescents. Using multivariate analysis, our study demonstrates that age, AN status, triglyceride level, and BMI z-score are significant independent variables associated with IR. Hopefully, a simple and practical prediction model of IR with acceptable sensitivity and specificity can be derived by combining these clinical findings, anthropometric measurements, and biochemical markers.

\section{Limitations}

Important limitations of this study included its retrospective design, being single-centred, and thus not being suitable for calculating populationbased rates. In addition, the stage of puberty (not documented) may also influence IR. Moreover, several relevant risk factors (family history of metabolic derangement, maternal gestational DM, duration of obesity, socio-economic status) were not included in the analysis. As in other retrospective studies, it was not possible to retrieve every single item of data. Notably, AN status was unavailable in $11(2 \%)$ patients while HOMA-IR information was absent in $46(8 \%)$ of the subjects, as fasting insulin levels were not checked and might have contributed to selection bias. Our study was clinic-based and not population-based, and so an overestimate of morbidity was a possibility. Besides, establishing a relationship between cause and effect was not possible due to the cross-sectional nature of the study. Growth data collected in 1993 (HK1993) are still widely used locally and seem appropriate in Hong Kong. ${ }^{9}$ We adopted the operational BMI cut-offs for daily use locally. However, the ideal cut-offs for being overweight and having obesity remain controversial, and various definitions and operational values exist. ${ }^{39}$ These problems may also limit direct comparisons between different studies using different growth references and cut-offs. ${ }^{39}$

\section{Conclusion}

Local obese Chinese children with AN are at higher risk of IR and cardiometabolic co-morbidities.
Primary care physicians should be vigilant for this clinical sign. If present, early attention is necessary to achieve early intervention. Further studies may be necessary to evaluate the longitudinal risk relationship between AN and cardiometabolic outcomes.

\section{References}

1. Caballero B. The global epidemic of obesity: an overview. Epidemiol Rev 2007;29:1-5.

2. So HK, Nelson EA, Li AM, et al. Secular changes in height, weight and body mass index in Hong Kong Children. BMC Public Health 2008;8:320.

3. Bao W, Srinivasan SR, Wattigney WA, Berenson GS. Persistence of multiple cardiovascular risk clustering related to syndrome $\mathrm{X}$ from childhood to young adulthood: the Bogalusa Heart Study. Arch Intern Med 1994;154:1842-7.

4. Knowler WC, Barrett-Connor E, Fowler SE, et al. Reduction in the incidence of type 2 diabetes with lifestyle intervention or metformin. N Engl J Med 2002;346:393-403.

5. Kong AS, Williams RL, Smith M, et al. Acanthosis nigricans and diabetes risk factors: prevalence in young persons seen in southwestern US primary care practices. Ann Fam Med 2007;5:202-8.

6. American Diabetes Association. Type 2 diabetes in children and adolescents. Diabetes Care 2000;23:381-9.

7. Ice CL, Murphy E, Minor VE, Neal WA. Metabolic syndrome in fifth grade children with acanthosis nigricans: results from the CARDIAC project. World J Pediatr 2009;5:23-30.

8. Kong AP, Choi KC, Ko GT, et al. Associations of overweight with insulin resistance, beta-cell function and inflammatory markers in Chinese adolescents. Pediatr Diabetes 2008;9:488-95.

9. So HK, Nelson EA, Sung RY, Ng PC. Implications of using World Health Organization growth reference (2007) for identifying growth problems in Hong Kong children aged 6 to 18 years. Hong Kong Med J 2011;17:174-9.

10. Ng DK, Lam YY, Kwok KL, Chow PY. Obstructive sleep apnoea syndrome and obesity in children. Hong Kong Med J 2004;10:44-8.

11. Leung SS, Cole TJ, Tse LY, Lau JT. Body mass index reference curves for Chinese children. Ann Hum Biol 1998;25:169-74.

12. Sung RY, Choi KC, So HK, et al. Oscillometrically measured blood pressure in Hong Kong Chinese children and associations with anthropometric parameters. J Hypertens 2008;26:678-84.

13. Nsiah-Kumi PA, Beals J, Lasley S, et al. Body mass index percentile more sensitive than acanthosis nigricans for screening Native American children for diabetes risk. J Natl Med Assoc 2010;102:944-9.

14. Matthews D, Hosker J, Rudenski A, Naylor B, Treacher D, Turner R. Homeostasis model assessment: insulin resistance and $\beta$-cell function from fasting plasma glucose and insulin concentrations in man. Diabetologia 1985;28:412-9.

15. Definition, diagnosis and classification of diabetes and its complications: report of a WHO consultation, part 1: diagnosis and classification of diabetes mellitus. Geneva, Switzerland: World Health Organization; 1999.

16. Brickman WJ, Huang J, Silverman BL, Metzger BE. Acanthosis nigricans identifies youth at high risk for 
metabolic abnormalities. J Pediatr 2010;156:87-92.

17. Atabek ME, Pirgon O, Kurtoglu S. Assessment of abnormal glucose homeostasis and insulin resistance in Turkish obese children and adolescents. Diabetes Obes Metab 2007;9:304-10.

18. Chitturi S, Farrell GC, Hashimoto E, et al. Non-alcoholic fatty liver disease in the Asia-Pacific region: definitions and overview of proposed guidelines. J Gastroenterol Hepatol 2007;22:778-87.

19. Smith WG, Gowanlock W, Babcock K, et al. Prevalence of acanthosis nigricans in First Nations children in Central Ontario, Canada. Can J Diabetes 2004;28:410-4.

20. Kong AS, Williams RL, Rhyne R, et al. Acanthosis nigricans: high prevalence and association with diabetes in a practice-based research network consortium-a PRImary care Multi-Ethnic network (PRIME Net) study. J Am Board Fam Med 2010;23:476-85.

21. Shalitin S, Abrahami M, Lilos P, Phillip M. Insulin resistance and impaired glucose tolerance in obese children and adolescents referred to a tertiary-care center in Israel. Int J Obes (Lond) 2005;29:571-8.

22. Kluczynik CE, Mariz LS, Souza LC, Solano GB, Albuquerque FC, Medeiros CC. Acanthosis nigricans and insulin resistance in overweight children and adolescents. An Bras Dermatol 2012;87:531-7.

23. Stuart CA, Pate CJ, Peters EJ. Prevalence of acanthosis nigricans in an unselected population. Am J Med 1989;87:269-72.

24. Singh B, Saxena A. Surrogate markers of insulin resistance: a review. World J Diabetes 2010;1:36-47.

25. Keskin M, Kurtoglu S, Kendirci M, Atabek ME, Yazic C. Homeostasis model assessment is more reliable than the fasting glucose/insulin ratio and quantitative insulin sensitivity check index for assessing insulin resistance among obese children and adolescents. Pediatrics 2005;115:e500-3.

26. Studies to Treat or Prevent Pediatric Type 2 Diabetes Prevention Study Group. Prevalence of the metabolic syndrome among a racially/ethnically diverse group of U.S. eighth-grade adolescents and associations with fasting insulin and homeostasis model assessment of insulin resistance levels. Diabetes Care 2008;31:2020-5.
27. Goran MI, Ball GD, Cruz ML. Obesity and risk of type 2 diabetes and cardiovascular disease in children and adolescents. J Clin Endocrinol Metab 2003;88:1417-27.

28. Sorof JM, Lai D, Turner J, Poffenbarger T, Portman RJ. Overweight, ethnicity, and the prevalence of hypertension in school-aged children. Pediatrics 2004;113:475-82.

29. Jessup A, Harrell JS. The metabolic syndrome: look for it in children and adolescents, too! Clin Diabetes 2005;23:2632.

30. El-Atat FA, Stas SN, McFarlane SI, Sowers JR. The relationship between hyperinsulinemia, hypertension and progressive renal disease. J Am Soc Nephrol 2004;15:281627.

31. Reinehr T, de Sousa G, Toschke AM, Andler W. Comparison of metabolic syndrome prevalence using eight different definitions: a critical approach. Arch Dis Child 2007;92:1067-72.

32. Fang J, Zhang JP, Luo CX, Yu XM, Lv LQ. Carotid intimamedia thickness in childhood and adolescent obesity relations to abdominal obesity, high triglyceride level and insulin resistance. Int J Med Sci 2010;7:278-83.

33. Bray GA. Medical consequences of obesity. J Clin Endocrinol Metab 2004;89:2583-9.

34. Uwaifo GI, Tjahjana M, Freedman RJ, Lutchman G, Promrat K. Acanthosis nigricans in patients with nonalcoholic steatohepatitis: an uncommon finding. Endocr Pract 2006;12:371-9.

35. Sartorio A, Del Col A, Agosti F, et al. Predictors of nonalcoholic fatty liver disease in obese children. Eur J Clin Nutr 2007;61:877-83.

36. Koot BG, van der Baan-Slootweg OH, Bohte AE, et al. Accuracy of prediction scores and novel biomarkers for predicting nonalcoholic fatty liver disease in obese children. Obesity (Silver Spring) 2013;21:583-90.

37. Oldroyd J, Banerjee M, Heald A, Cruickshank K. Diabetes and ethnic minorities. Postgrad Med J 2005;81:486-90.

38. Huen KF, Low LC, Cheung PT, et al. An update on the epidemiology of childhood diabetes in Hong Kong. Hong Kong J Paediatr 2009;14:252-9.

39. Rolland-Cachera MF. Childhood obesity: current definitions and recommendations for their use. Int J Pediatr Obes 2011;6:325-31. 